УДК: $7.032(38)$

ББК: 63.3(0)32; 85.126

DOI: $10.18688 / \mathrm{aa} 2111-01-03$

M.N. Nenakhova

\title{
Clazomenian Sarcophagus from the British Museum: The Semantic Aspects of the Decoration and Shape
}

The decorated terracotta sarcophagi named "Clazomenian" by the scientists after the principal place of discovery and supposed production center mainly come from the Ionian coast of Asia Minor (Clazomenae, Old Smyrna, Ephesus and Miletus), as well as from the island of Rhodes. They have been extensively studied in the $19^{\text {th }}[11 ; 37 ; 31]$ and during the $20^{\text {th }}$ century when the focus was made mostly on stylistics, classification, dating, and the genesis of their form. These issues still remain important because new findings and new archaeological data constantly improve our knowledge of this remarkable group of historical items. At the same time, one of the most intriguing questions regarding Clazomenian sarcophagi is the interpretation of their unique figurative decoration.

The scenes depicted on the sarcophagi look like narratives, but the lack of clear links to mythological stories or epics makes them difficult to explain. The other problem is the scarcity of reliable sources to support any interpretation. Most painted sarcophagi kept in museums have lost their original context by now. And some new findings coming from regular excavations have not been published or available for study. We also have insufficient information about the religious beliefs of the Clazomenians, as well as the social status of those who ordered the sarcophagi. Therefore, when analyzing this material, we should turn to the paintings themselves and to the artistic and literary parallels that may confirm our assumptions.

The most important contribution to the study of sarcophagi was made by Robert M. Cook in his monograph "Clazomenian sarcophagi" (1981) [9], which contains a catalogue and classification with extensive comments. This is the first and the only work with such an approach to this material. In analyzing figurative paintings, Cook raises the question of their subjects and identifies several scenes that could be correlated to popular epics. In his opinion, the majority of paintings are difficult to associate with any myth, as the images are typified and devoid of a narrative component. Based on this assumption, Cook concludes that the main function of the paintings is decorative [9, p. 115]. A similar opinion was expressed earlier, for instance, by K. F. Johansen in 1942 [25]. This idea continues to find support today, for example, in the article by S. Ahrens and A. Habu, 2005 [2].

Elfi Kirchner, a German researcher, challenges this conclusion [27]. She also believes that the narrative component in the paintings is not a crucial one, but it does not mean a lack of semantic content. She interprets the paintings as a set of "pictorial formulas," a system of "hieroglyphic" images in which each figure or their combination is a symbolic code [27, p. 128] that could be associated with Clazomenian funerary and religious traditions. This approach is 
supported by other researchers (N. Papalexandrou [39], B. Gronvold [17] and E. R. Asandoae [3]) and seems to be the most promising one.

In our study, we use this methodology for clarifying the iconographic and semantic aspects of the decoration. At the same time, it is possible to go a bit further and combine the semantic interpretation of the paintings with the analysis of the spatial structure of the sarcophagi. It is the sarcophagus as a whole, and not just its decoration, that brings together all the main themes and meanings. Key image-formulas (the various versions of the battles, agones, mixomorphic creatures, ornaments, etc.) are depicted in certain locations on the lid and on the different parts of the coffin that are covering, framing, and enclosing structural elements. The meaning and character of the paintings may be determined by their location. According to our knowledge, this aspect has never been considered.

In the search of an approach to such a complex phenomenon as Clazomenian sarcophagi decorations, we will try to test our method on one of the most outstanding examples - a sarcophagus from the British Museum (Ill. 1) belonging to the Albertinum group dating to 510-480 BC. This sarcophagus, which was designated with the letter G1 [9, p.31], is notable for its unique integrity and rich decoration. The scenes and their combinations are typical for Albertinum group sarcophagi, which include the most exquisite items in terms of decoration. However, this sarcophagus is notable for its exceptional concentration of subjects and a great number of images that make it a good target for our case study.

The G1 sarcophagus decoration can be divided into external (painting on the coffin lid) and internal (in contact with the body in the interior of the sarcophagus). The painting on the two rims - one on the chest and the other on the lid - incases the body and serves as a transition from the external to the internal decoration. Thus, all figurative and ornamental compositions relate to the structure with the body in the center: a lid covering like a baldachin, a double rim incasing the body like a portal, and finally the interior of the sarcophagus.

The crowning part, as well as the sarcophagus itself, resembles wooden forms similar to chests that may refer to the Minoan tradition of burials in larnax sarcophagi [30, p. 4]. Contacts between Clazomenae and Crete are confirmed by Minoan pottery of 1500-1200 BC [13, p.6], and in the Early Archaic period there was a custom to bury people in small bath-like sarcophagi that has parallels in the Cretan tradition [8, p. 65].

At the same time, the lid of the G1 sarcophagus clearly imitates architectural forms, as it has a cornice and pediments. A column is depicted in the center of both pediments. On one side, it is flanked by warriors leading horses and winged geniuses, and on the other side by two centaurs and sphinxes. Thus, we have a pediment composition with a central vertical element, which is also an axis of symmetry for heraldic images. Some interesting parallels to this feature can be found in the cult and funerary architecture of Lycia in Asia Minor $\left(5^{\text {th }}-4^{\text {th }}\right.$ centuries BC). The closest analogue to the decoration of the British Museum sarcophagus is the pediment relief, which is attributed to "Building F" on the Xanthos acropolis [24, pp. 173-174] dating to the $5^{\text {th }}$ century BC. In the center, there is an image of a column with a siren sitting on it (this mixomorphic creature often found on the Clazomenian sarcophagi has clear funerary associations in the Greek world) and two male figures on the sides. It should be noted that "Building F" (among others) was interpreted as a heroon (hero's shrine) [24, p. 169], which is significant in the context of our study. 
In the case of the G1 sarcophagus, the dividing column is installed on a stepped pedestal and, most likely, acts as a marker of the hero's grave. This motif is well attested in Greek art in vase paintings, and on white background lekythoi in particular. The sarcophagus pediment shows young men leading their horses, which could be interpreted as a sacrificial ritual. Here we see a Homeric association with the burial of Patroclus in the Iliad (Hom. Il. XXIII, 171-172):

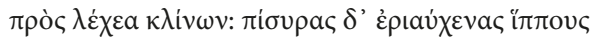

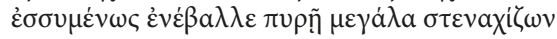

leaning them against the bier; and four horses

with high arched neeks he cast swiftly upon the pyre, groaning aloud the while

(Translation by A. T. Murray, 1924)

The slopes of the coffin lid indicated as A and B are divided into three friezes. The patterns are never repeated, but the similarity of the compositional logic can be traced. The lower register on side $\mathrm{A}$ is covered with scenes of battles between groups of hoplites and horsemen accompanied by dogs. The riders wear high headdresses and carry short swords and goryti, that, according to Cook, indicates their "non-Greek" origin, and they are usually considered Persians [9, p. 117]. Many examples of similar complex battle scenes can be found in Archaic black-figure vase paintings. However, battles involving hoplites and "barbarian" horsemen are very rare. It is noteworthy that on side B of the same register, there is a frieze with a standard alternation of hoplites in a battle. We can hypothesize that on side A some local realities may be reflected, since neighboring Lydia had a strong cavalry, as mentioned by Herodotus (Hdt. I, 79). A.S. Murray points to the use of dogs in combat as an Anatolian tradition [31, p.2].

On the upper frieze, we encounter the column's motif as well, but this time in the form of a limiter (meta) in chariot races. This motif echoes the funeral games in honor of Patroclus (Hom. XXIII, 327-328). This meta is indicated in the Homeric text by the noun $\xi \dot{v} \lambda$ ov (piece

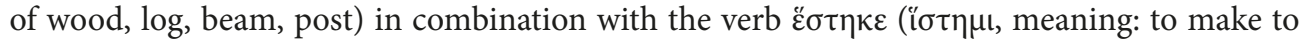
stand), and at the same time the meta is a burial mark.

The chariot itself is an important attribute of high status, strength and power [33, p. 169]. And the chariot race is a fairly stable motif in the decoration of Clazomenian sarcophagi. It indicates particular ambitions of the local elite who wanted to emphasize the connection with the Heroic Age and the legendary past of the region. However, Clazomenian paintings obviously do not show real agones of the past or present but some kind of "non-earthly" and heroic event. For example, winged creatures accompanying chariots also appear in vase paintings. They are interpreted as the souls of the deceased and the winged replicas of the body [45, p.9]. In our case, the creatures have Nike's attributes: they hold wreaths over young men, which may mean glory, including the posthumously.

It is worth noting the giant flower buds above the heads of the hoplites and charioteers, which is probably associated with Elysium. We find similar half-opened buds in the Attic vase painting of the $6^{\text {th }}$ century BC. On the Sian kylix with the scene of the Hercules's apotheosis, a huge bud grows from Zeus's throne. Perhaps, their appearance next to the warriors can be considered as a sign of prosperity of the latter in the afterlife $[35,131]$. The chariots are driven by naked charioteers, which may indicate the "non-earthly" and heroic nature of the agon. 
There is a figurative group of two hoplites bent over an archer in the center of the upper frieze. The archer depicted in a subordinate position wears a "barbaric" dress with a gorytus on his hip. This scene is repeated several times in the decoration of the sarcophagus. Perhaps this is a prisoner's death or execution. In combination with chariot races, it might be the ritual death at a hero's grave - an analogy of the sacrifice at the grave of Patroclus (Hom. Il. XXIII, 181-182).

There are dividing friezes with animals in the center of each side of the lid. There are fantastic animals (sphinxes and sirens) on side A and real ones (a boar, a lion, a panther, and a goat) on side B. The semantics of these images are associated with apotropaic and burial (on side A), as well as heroic and epic (on side B) subjects. Similar animal friezes in combination with battle scenes are known in the Attic vase painting of the $6^{\text {th }}$ century BC. For example, the Tyrrhenian amphora of the Prometheus Painter (570-560 BC) is divided into three friezes. The upper frieze represents the battle of Achilles and Memnon, while the two lower friezes show fantastic beasts (sphinxes and sirens) and real ones (rams, panthers, lions, and birds). Here we can see the same principle of composition with two identical creatures "meeting" in the center. It may be interpreted as an allegorical representation of conflict between two brave warriors and the forces that protect them. Strong, aggressive animals repeatedly depicted on side B follow the same compositional principle of multiplication as in the battle scenes and may contain allusions to war in general.

The painting inside the lid (on the rim) is not completely preserved. Its sides are decorated with ornamental patterns and symmetrical metopic images of sphinxes, as well as with the aforementioned motif of two hoplites killing an archer. The remaining short side of the rim shows chariot scenes and a duel over a fallen hoplite in the center. It seems that these are the abbreviated versions of the scenes and ideas that are more extensively presented on the outer friezes of the lid.

The sarcophagus rim is also decorated with symmetrical compositions of chariot races (Ill. 2), but a new detail appears - a crater erected on the column with an Aeolian capital - that is obviously a prize in the competition. It marks the ends of the longitudinal parts of the rim, but the symmetrical paintings are not entirely copied. On one side, an image of the column is complemented with a shield leaning against it, and next to it, there is a male figure. If the column symbolizes the grave where the race started, the figure, as suggested by Alexander Murray, may represent the shadow of the deceased, and the race itself is part of the funeral agon [31, p.6]. Kirchner notes the similarity with Homer's text describing Patroclus games as well, but at the same time, she emphasizes that the painting does not in any way "illustrate" the poem. Kirchner is also inclined to believe that real practices (of which we have no evidence) may be reflected in the sarcophagus paintings [27, p. 131]. Karin Tanke advanced the idea that these images can be echoing epic scenes as well as depicting aristocratic attributes (chariots, horses, and dogs) which really existed. These two suggestions do not exclude each other. Like Kirchner, she assumes this is a kind of pictorial code associated with a high social status [41, p. 110].

The structure and decoration of the internal part of the sarcophagus, which is in direct contact with the body, correspond to its external design, but it is devoid of figurative paintings. Some inner images are framed by a thin stripped ceramic braid. In longitudinal friezes, the arrangement of figures is less concentrated than on the lid, but the composition and rhythm are more complicated. 
A duel between two naked warriors armed with spears is depicted in the center. Between them, there is a young man playing the flute. The fight is characterized by more complicated, almost dance-like movements of the opponents, who step back bending their knees. It may be not a real battle but its agonal analogue. Cook believes that this is a depiction of pyrricha

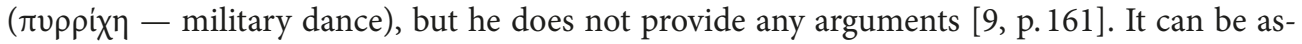
sumed that this duel must be understood as a scene of hoplomachia ( $\dot{\delta} \pi \lambda$ opaxia) - a combat between two armed warriors [9, p.116]. The Iliad includes the description of a similar duel between Diomedes and Ajax at Patroclus funeral games (Hom. Il. XXIII, 815-823). A very close visual analogy can be found on a hydria (late $6^{\text {th }}-$ early $5^{\text {th }}$ centuries BC) from the Metropolitan Museum of Art attributed to the Dikaios Painter (500 BC). Here the idea of peaceful agon is even more obvious. Analyzing this scene, G. M. A. Richter also points to the Homeric origin of the scenario [38, p. 33].

The representation of naked young men with crotala is associated with dancing and is not typical in the context of battles [46, p. 123]. This musical instrument was used mainly by women, as well as by young men at symposia [46, p. 125]. Satyrs and male dancers are often depicted with crotala in their hands [7, p. 286]. Thus, for the first time a "peaceful" analogue of a battle appears on the G1 sarcophagus. The alternation of chariots and hoplites also reminds us of the description of the funeral procession of Patroclus (Hom. Il. XXIII, 131-132):

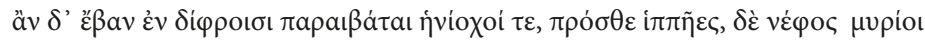

In front fared the men in chariots,

and thereafter followed a cloud of footmen

(Translation by A. T. Murray, 1924)

Perhaps we observe the beginning of the actions in honor of the deceased. The warriors met in a duel, and the young men are getting ready for the chariot agon.

A hoplite flanked by warriors leading horses by the bridle and accompanied by dogs is depicted on the central panels in the short sides (Ill. 3). These scenes correspond to the position of the head and legs of the deceased; the figures of hoplites are on the central axis. Here we have, in fact, a repeated scheme represented on the lid pediment, but the column-like tombstone is replaced by a warrior figure. Hidden inside the box, the scene becomes more "personalized." It is not the column marking the hero's grave that is depicted but the warrior himself or his shadow.

Giant buds also appear on the inner parts. They are always located next to hoplites, which can also be interpreted as the motif of the beautiful and fragrant Elysian meadows, where the chosen heroes enjoy a carefree eternal existence [34, p. 28; 33, p. 110].

In summary, having inherited the tradition of richly decorated chests, the G1 sarcophagus gained more resemblance to monumental forms due to architectural allusions that were supposed to make it more significant and perhaps to form associations with tombs or heroons. This tendency probably has parallels in the development of stone sarcophagi. It is appropriate to mention in this regard the famous marble "Sarcophagus of Polyxena" (late $6^{\text {th }}$ century BC) found in the mound of Kızöldün in Asia Minor [12, p. 172]. Its upper part was made in the form of a roof with pediments, tiles, partially lost acroteria, and a multi-stage cornice. The sarcoph- 
agus chest is decorated with magnificent reliefs depicting ritual scenes and a subject from the Trojan cycle.

If our assumptions are correct, the model of the "hero's tomb" can be "reconstructed" in the following way: the lid is raised like a "mound", the columns at the ends are burial markers. Here, at the funeral pillar, battle scenes echoing epic stories take place. The inner space is preceded by a "portal" from the sarcophagus chest and lid rims. The chariot races, pillars or marks and possibly the spirit of the deceased are depicted here, as well as precious prize cauldrons and the scenes of a prisoner being killed. These images as a whole can be interpreted as the farewell to a hero at the doorway of his new "home" or, if taking into account the winged creatures and the motif of giant buds, as a celebration in honor of a hero's arrival in Elysium. The entrance to the underworld is guarded by sphinxes on the lid rims.

There are no battle scenes in the sarcophagus interior. Tensions go away and the motif of dancing, music, and peaceful agones appears. The formal language of symmetry dominates here and the decoration becomes more structured and formulary. The moment of doubling and axial rollovers is emphasized: opposite walls reflect each other like in a mirror and important semantic symbols are duplicated. Perhaps the decoration of all parts of the sarcophagus in its integrity was intended to give a clear reference to a real or imaginary funeral ritual that would guarantee a place for the deceased among the heroes of the past.

It should be noted that the Albertinum group includes the most exquisite sarcophagi in terms of the decoration and form. There are several more also having architectural elements, but, unfortunately, they are in a poorer condition. Thus, we have reason to assume the tendency for making sarcophagi more monumental in the late $6^{\text {th }}-$ early $5^{\text {th }}$ centuries BC.

The reasons for this phenomenon require further study. We hope that the ongoing excavations in the territory of ancient Clazomenae will provide us with the reliable information that will allow us to reconstruct the beliefs, funeral rites, and their patterns in this region.

\section{References}

1. Akurgal E. The Art of Greece. Its Origins in the Mediterranean and Near East. New York, Crown Publishers Inc., 1966. 258 p.

2. Ahrens S.; Habu A. En klazomensk sarkofag i Oslo. Viking, iss. 63, 2005, pp. 151-164 (in Norwegian).

3. Asandoae E. R. Fantastic Representation on Clazomenian Sarcophagi. Sîrbu V.; Jevtić M.; Dmitrović K.; Ljuština M. (eds.). Funerary Practices during the Bronze and Iron Ages in Central and Southeast Europe, 2016, pp. 209-224.

4. Aytaclar N. The Early Iron Age at Klazomenai. Moustaka A.; Skarlatidou E.; Tzannes M.-C.; Ersoy Y. (eds.). Klazomenai, Teos and Abdera: Metropoliesans and Colony. Proceedings of the International Symposium held at the Archaeological Museum of Abdera. Thessaloniki, 2004, pp.29-30.

5. Burkert W. The Orientalizing Revolution. Near Eastern Influence on Greek Culture in the Early Archaic Age. London, Harvard University Press Publ., 1998. 225 p.

6. Byvanck A. W. Some Remarks on Clazomenian Sarcophagi. L'antiquité classique, fasc. 1. Miscellanea Philologica Historica et archaelogia in honorem Huberti Van De Weerd, vol. 17, 1948, pp. 93-100.

7. Castaldo D. The Sound of Krotala Maddening Women. Ytromanolakis D. (ed.). Archeology of Representations. Greek Vase-Painting and Contemporary Methodologies. Athens, Institute du Livre Publ., 2009, pp. 284-298.

8. Cevizoglu H. Klazomenian Sarcophagus or Bathtub? The Use of Bathtubs in Burial Contexts. Gürtekin-Demir R. G.; Cevizoğlu H.; Polat Y.; Polat G. (eds.). Proceedings of the First International Conference at Ege University May 9-13. Izmir, Bilgin Publ., 2011, pp.61-72. 
9. Cook R. M. Clazomenian sarcophagi. Mainz, von Zabern Publ., 1981. 184 p.

10. Cook R. M.; Dupont P. East Greek Pottery. Routledge Readings in Classical Archaeology Series. London, Routledge Publ., 1997, pp. 123-152.

11. Dennis G. Two Archaic Greek Sarcophagi Recently Discovered in the Necropolis of Clazomenae. The Journal of Hellenic Studies, iss. 4, 1883, pp.1-22.

12. Dusinberre E. R.M. Empire, Authority, and Autonomy in Achaemenid Anatolia. Cambridge, Cambridge University Press Publ., 2013. 397 p.

13. Ersoy Y.E. Clazomenae. The Archaic Settlement, Ph. D. Dissertation. UMI, 1993. 860 p.

14. Ersoy Y.E. Notes on History and Archeology of Early Clazomenae. Cobet J.; von Graeve V.; Niemeier W.D.; Zimmermann K. (eds.). Frühes Ionien Eine Bestandsaufnahme. Panionion. Symposion Güzelçamlı 26. September - 1. Oktober 1999, pp. 149-178.

15. Ersoy Y.E. Klazomenai: 900-500 BC. History and Settlement Evidence. Moustaka A.; Skarlatidou E.; Tzannes M.-C.; Ersoy Y. (eds.). Klazomenai, Teos and Abdera: Metropoleis and Colony, Proceedings of the International Symposium held at the Archaeological Museum of Abdera. Abdera, University Studio Press Publ., 2004, pp. 43-76.

16. Gaebel R.E. Cavalry Operations in the Ancient Greek World. Norman, University of Oklahoma Press, 2002. $345 \mathrm{p}$.

17. Gronvold B. Protection and Display. Oxford, Wilson College, 2014, pp. 1-28.

18. Herodotus. History. Leningrad, Nauka Publ., 1972. 600 p. (in Russian).

19. Homer. Iliad. Moscow, State publishing house of fiction, 1960. 435 p. (in Russian).

20. Hürmüzlü B. Burial Grounds at Klazomenai: Geometric through Hellenistic Periods. Moustaka A.; Skarlatidou E.; Tzannes M.-C.; Ersoy Y. (eds.). Klazomenai, Teos and Abdera: Metropoleis and Colony, Proceedings of the International Symposium held at the Archaeological Museum of Abdera, Abdera, 20-21 October 2001. Thessaloniki, 2004, pp. 149-178.

21. Hürmüzlü B. A New Type of Clazomenian Sarcophagus: The Alteration of the Burial Customs in Clazomenae. Bol R.; Kreikenbom D. (eds.). Sepulkral- und Votivdenlmaler ostlicher Mittelmeergebriete (7. Jh. v. Chr. - 1. Jh. n. Chr). Mainz, Bibliopolos Publ., 2004, pp. 195-199.

22. Hürmüzlü B. The Organization and Utilization of the Burial Grounds in Klazomenai. Olba, iss. 12, 2005, pp.39-67.

23. Hürmüzlü B. Die Früheste Gruppe Klazomenischer Sarkophage aus Klazomenai. Jahrbuch des Deutschen Archaologischen Instituts, iss. 125, 2010, pp. 89-153 (in German).

24. Jenkins I. Greek Architecture and its Sculpture. Cambridge, Cambridge University Press Publ., 2006. 271 p.

25. Johansen, K.F. Attic Motives On Clazomenian Sarcophagi. From The Collections of The Ny Carlsberg Glyptothek. Clazomenian Sarcophagus Studies: The Earliest Sarcophagi. Acta Archaeologica, iss. 8, 1942, pp. 123-143.

26. Kerschner M. The Lydians and Their Ionian and Aeolian Neighbors. Cahill N.D. (ed.). The Lydians and Their World. Istanbul, 2010, pp. 247- 265.

27. Kirchner E. Zum Bildprogramm Klazomenische sarkophage. Jahrbuch des Deutschen Archäologischen Instituts, iss. 102, 1987, pp. 121-156 (in German).

28. Kisbali T. P. Sculptural Program of the Mausoleum at Halicarnassus. Zakharova A. V. (ed.). Actual Problems of Theory and History of Art: Collection of Articles, vol.3. St. Petersburg, 2013, pp. 60-64 (in Russian).

29. Lapteva M. U. U istokov drevnegrecheskoi tsivilizatsii. Ionia XI-VI veka do n.e. (At the Origins of Ancient Greek Civilization. Ionia $11^{\text {th }}-6^{\text {th }}$ BCE). St. Petersburg, Humanities Academy Publ., 2009. 512 p. (in Russian).

30. McGeorge P. J. P. Intramural Infant Burials in the Aegean Bronze age. Henry O. (ed.). Le Mort Dans La Ville. Institut Français d'Études Anatoliennes Georges Dumézil, 2011, pp. 1-20.

31. Murray A.S. Terracotta Sarcophagi. Greek and Etruscan in British Museum. London, British Museum Publ., 1898, pp. 1-28.

32. Nalimova N.; Savina I. Creating Monumental Tombs of Cyprian Salamis: The Role of the Funeral Rites, the Prototypes and Parallels. Zakharova A. V.; Maltseva S. V.; Staniukovich-Denisova E. Iu. (eds.). Actual Problems of Theory and History of Art: Collection of Articles, vol. 9. Moscow, Lomonosov Moscow State University; St. Petersburg, NP-Print Publ., 2019, pp. 30-44 (in Russian). DOI: 10.18688/aa199-1-3

33. Nalimova N. The Origin and Meaning of Floral Imagery in the Monumental Art of Macedonia $\left(4^{\text {th }}-3^{\text {rd }}\right.$ Centuries BC). Macedonia - Rome - Byzantium: The Art of Northern Greece from Antiquity to the Middle Ages, Proceedings of a Conference. Moscow, University Book Publ., 2017, pp. 13-35. 
34. Nalimova N.A. Scenes of Chariot Competition in the Funerary Art of the $4^{\text {th }}$ BCE: Halicarnassus and Verginian Friezes. Ancient Near East and Antique World: Collection of Articles of MSU' History Department, vol. 9, 2018, pp. 159-179 (in Russian).

35. Nalimova N. Gold Flowers to Flame on Land. On The Pictorial Program of the Tomb of Palmettes at Mieza. Danilov Readings. Antiquity - Middle Ages - Renaissance: Collection of Articles and Materials. Moscow, New literary review Publ., 2018, pp. 96-112 (in Russian).

36. Palagia O. In the Shadow of Cimon: From Late Archaic To Early Classical in Xanthos. From Hippias to Kallias. Greek Art from 527 to 449 B. C. International Conference at Acropolis Museum, Athens, May 19-20. Athens, Acropolis Museum Publ., 2019, pp. 279-287.

37. Reinach S. Un nouveau sarcophage peint de Clazomène au Musée de Constantinople. Revue des Études Grecques, fascicule 30, vol. 8, 1895, pp.161-182 (in French).

38. Richter G.M. A. Red Figured Athenian Vases in the Metropolitan Museum of Art, vol.1. Oxford, Oxford University Press Publ., 1936. 540 p.

39. Papalexandrou N. A Clazomenian Sarcophagus in the Princeton University Art Museum. Record of the Art Museum, Princeton University, vol. 69, 2010, pp.4-21.

40. Price E. R. Kjellberg's New Class of Clazomenian Sarcophagi. The Journal of Hellenic Studies, vol. 50. 1, 1930, pp. $80-88$.

41. Tancke K. Wagenrennen. Ein Friesthema der aristokratischen Repräsentationskunst spätklassik-frühhellenistischer Zeit. Jdi, iss. 105, 1990, pp.95-127 (in German).

42. Tarakçı S. K. Some Remarks on Newly Discovered Graves at Klazomenai. Keramos Ceramics: A Cultural Approach. Proceedings of the First International Conference at Ege University May 9-13, 2011. Tzmir, Bildgin Publ., 2011, pp. 173-179.

43. Tzannes M.-C. The Excavations of G. Oikonomos at the Archaic Cemetery of Monastirakia in Klazomenai, 1921-22. Moustaka A.; Skarlatidou E.; Tzannes M.-C.; Ersoy Y. (eds.). Klazomenai, Teos and Abdera: Metropoleis and Colony, Proceedings of the International Symposium held at the Archaeological Museum of Abdera, Abdera, 20-21 October 2001. Thessaloniki, 2004, pp.97-120.

44. Ulusoy P. The Burial Customes of Clazomenae in the Iron Age (1100 - 500 BC), Department of Archaeology and History of Art. Ankara, Bilkent University Ankara Publ., 2010. 203 p.

45. Vermeule E. Aspects of Death in Early Greek Art and Poetry. California, University of California Press Publ., 1981. $270 \mathrm{p}$.

46. West M. L. Ancient Greek Music. Oxford, Oxford University Press Publ., 1994. 400 p. Shape

Title. Clazomenian Sarcophagus from the British Museum: The Semantic Aspects of the Decoration and

Author. Nenakhova, Maria Nikolaevna - Ph. D. student. Lomonosov Moscow State University, Leninskie Gory, 1, 119991 Moscow, Russian Federation. Maria_nenahova@mail.ru ORCID: 0000-0002-4178-6324

Abstract. In Asia Minor, richly decorated terracotta sarcophagi of the $6^{\text {th }}-5^{\text {th }}$ centuries BC were found in the necropolises of several Ionian centers: Clazomenae, Old Smyrna, Miletus, etc. The problem of "decoding" the paintings on these funerary items has remained since the end of the $19^{\text {th }}$ century. Today, two points of view on the problem coexist in art history. The first is that the paintings bear purely a decorative function and do not carry additional connotations (R.M.Cook and others), and the second is that the paintings are a kind of a "code" or "language" expressed in the images and their combinations to reflect the Clazomenian burial rites and religious beliefs (E. Kirchner and others). The article expands on the second point of view. It proposes to combine the semantic understanding of paintings with the analysis of the form using the example of the Clazomenian sarcophagus from the British Museum (510-480 BC). Not only the decoration but the sarcophagus as a whole brings together all the main subjects and meanings. The key symbolic images (various battles scenes, agones, mixomorphic creatures, ornamentation, etc.) have a certain location on the lid and chest - the covering, framing and enclosing structural elements. This can be explained by the internal logic of the sequence of "events": from battles (and death) to funeral games and finally an arrival in Elysium. From the comprehensive reading of the form and the decoration, the basic idea of the sarcophagus-heroon is formulated, which in semantic terms is comparable to the Anatolian burial structures of the same period.

Keywords: Clazomenian terracotta sarcophagi, Archaic period, funeral cult, funeral rite, black-figure painting, heroon, agon, chariot races, hoplite battles 
Название статьи. Клазоменский саркофаг из Британского музея: семантические аспекты декора и формы

Сведения об авторе. Ненахова Мария Николаевна - соискатель. Московский государственный университет им. М. В. Ломоносова, Ленинские горы, 1, Москва, Российская Федерация, 119991. Mariya_ nenahova@mail.ru ORCID: 0000-0002-4178-6324

Аннотация. На территории Малой Азии были найдены терракотовые, богато декорированные саркофаги VI-V вв. до н.э. в некрополях нескольких ионийских центров: Клазомены, Старая Смирна, Милет и некоторые другие. Проблема «расшифровки» росписей данных предметов погребального обряда остаётся актуальной с конца XIX в. Сегодня в искусствоведении сосуществуют две точки зрения на проблему. Первая - росписи декоративны и не несут в себе дополнительных коннотаций (Р. М. Кук и др.), вторая - росписи представляют собой некий «код» или «язык», выраженный в образах и их комбинациях для отражения погребальных верований клазоменцев (Э. Кирхнер и др).

Данная статья развивает вторую точку зрения. В ней предлагается соединить семантическое осмысление росписи с анализом формы на примере клазоменского саркофага из Британского музея (510480 гг.). Именно саркофаг как целое, а не только его декор, аккумулирует все главные темы и смыслы. Изображение ключевых формул-образов (различных вариантов изображений битв, агонов, миксоморфных существ, орнаментов и пр.) имеет определённое расположение на крышке и ящике - осеняющих, обрамляющих и вмещающих элементах конструкции. Это продиктовано внутренней логикой последовательности «событий»: от битвы (и гибели) до погребальных игр и пребывания в Элизии. Из комплексного прочтения формы и декора складывается основная идея саркофага-«героона», что в смысловом отношении сопоставимо с анатолийскими погребальными сооружениями того же времени.

Ключевые слова: Клазоменские терракотовые саркофаги, архаический период, погребальный культ, погребальный обряд, чернофигурные росписи, героон, агон, гонки колесниц, битвы гоплитов 


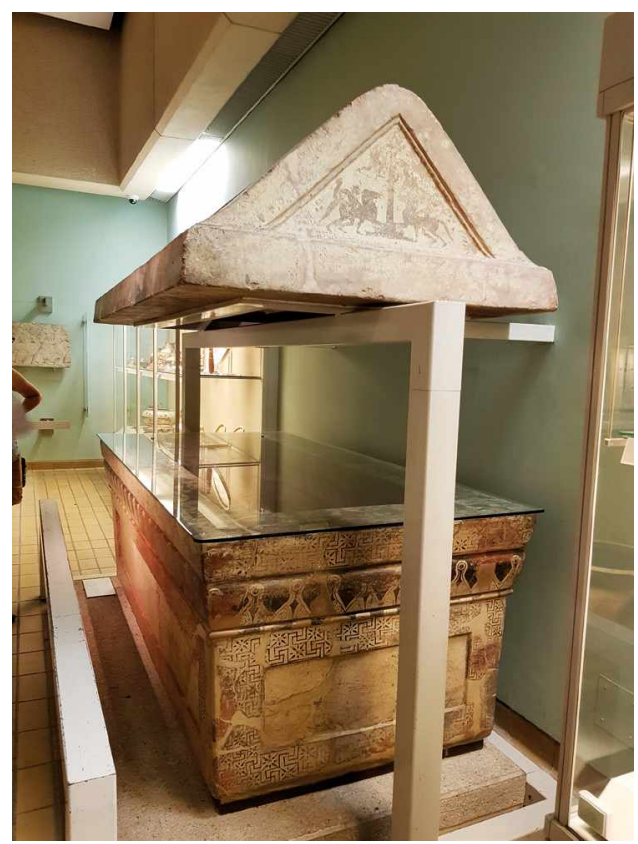

Ill. 1. Clazomenian sarcophagus. 510-480 BC. 1896,0615.1. The British Museum, London. Photo by M.N. Nenakhova

Ill. 3. Fragment of Clazomenian sarcophagus. 510-480 BC. 1896,0615.1. The British Museum, London. @ The Trustees of the British Museum

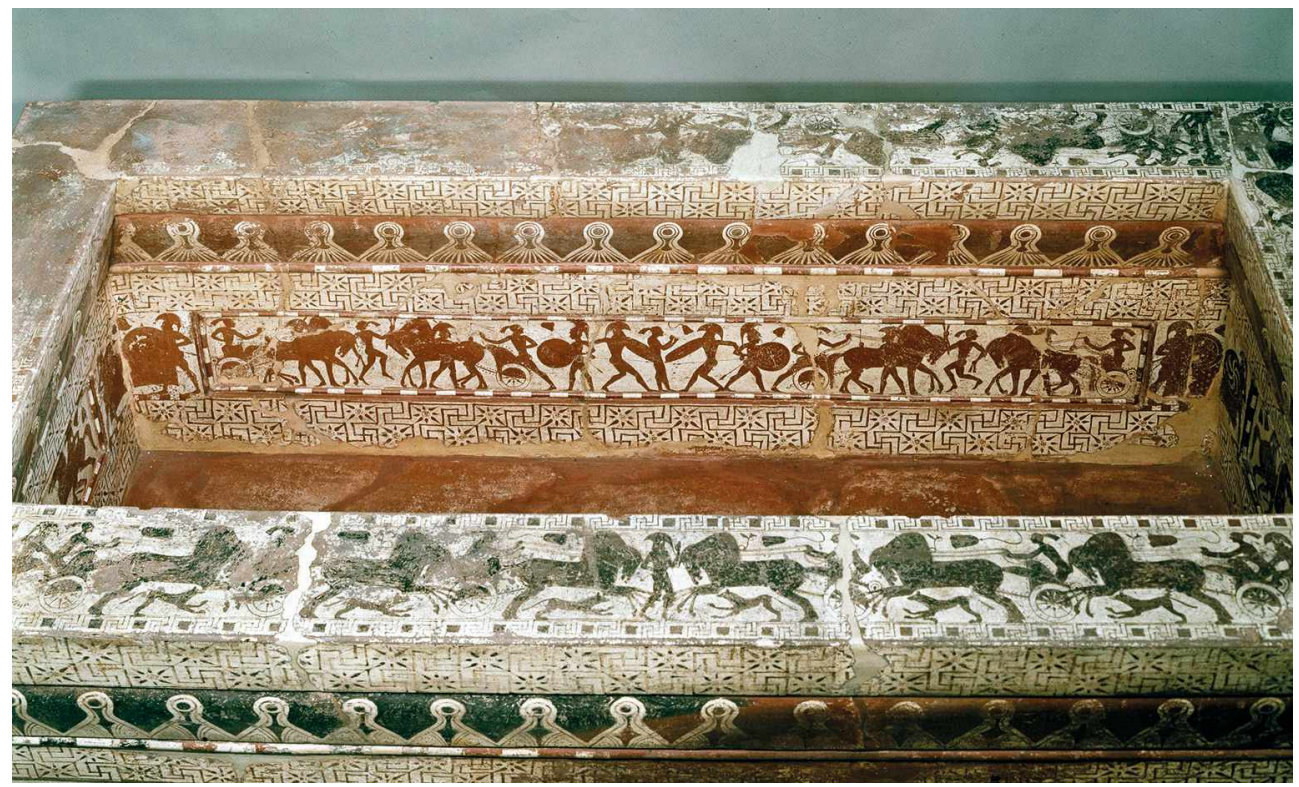

Ill. 2. Fragment of Clazomenian sarcophagus. 510-480 BC. 1896,0615.1. The British Museum, London. @ The Trustees of the British Museum 